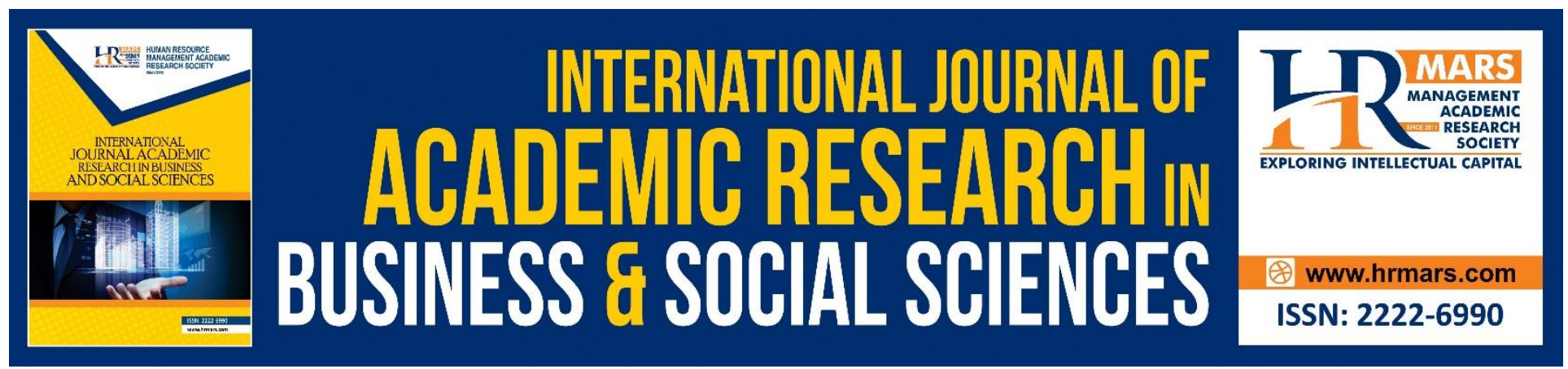

\title{
Child Marriage, A Culturally Accepted Privilege of Orthodoxies: The Case of Pakistan
}

\author{
Abdullahi Ayoade Ahmad, Sobia Jamil, Syed Zohaib Abbas Rizvi, Nasa’i Muhammad \\ Gwadabe
}

To Link this Article: http://dx.doi.org/10.6007/IJARBSS/v8-i12/5255

DOI: $10.6007 /$ IJARBSS/v8-i12/5255

Received: 21 Nov 2018, Revised: 29 Dec 2018, Accepted: 02 Jan 2019

Published Online: 16 Jan 2019

In-Text Citation: (Ahmad, Jamil, Rizvi, \& Gwadabe, 2018)

To Cite this Article: Ahmad, A. A., Jamil, S., Rizvi, S. Z. A., \& Gwadabe, N. M. (2018). Child Marriage, A Culturally Accepted Privilege of Orthodoxies: The Case of Pakistan. International Journal of Academic Research in Business and Social Sciences, 8(12), 1527-1539.

Copyright: (C) 2018 The Author(s)

Published by Human Resource Management Academic Research Society (www.hrmars.com)

This article is published under the Creative Commons Attribution (CC BY 4.0) license. Anyone may reproduce, distribute, translate and create derivative works of this article (for both commercial and non-commercial purposes), subject to full attribution to the original publication and authors. The full terms of this license may be seen at: http://creativecommons.org/licences/by/4.0/legalcode

Vol. 8, No. 12, 2018, Pg. 1527 - 1539

http://hrmars.com/index.php/pages/detail/IJARBSS

JOURNAL HOMEPAGE

Full Terms \& Conditions of access and use can be found at http://hrmars.com/index.php/pages/detail/publication-ethics 


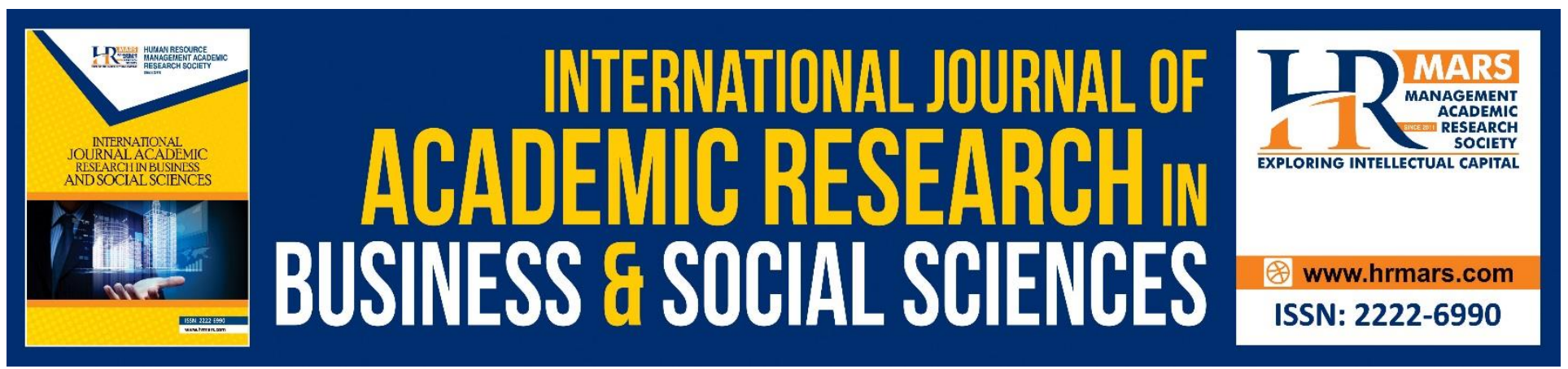

\title{
Child Marriage, A Culturally Accepted Privilege of Orthodoxies: The Case of Pakistan
}

\author{
Abdullahi Ayoade Ahmad, Sobia Jamil \\ Faculty of Law and International Relations, University of Sultan Zainal Abidin, Gong Badak Campus, \\ 21300 Kuala Nerus, Terengganu, Malaysia \\ Syed Zohaib Abbas Rizvi \\ University of the Punjab, Department of Political Science Pakistan
}

\section{Nasa'i Muhammad Gwadabe}

Department of History and International Studies Northwest University, Kano Nigeria

\begin{abstract}
Child marriage is universally believed to be the marriage under the age of eighteen. In other words, an immature or irresponsible person that has no ability to act independently. Child marriage practice is rampant in several countries. Poverty, illiteracy and gender inequality are the main causes of child marriages which affect the victims physically, socially, psychologically and economically. Apart from these reasons, a traditional assembly of leaders (Jirgas) in Pakistan endorses the practice of wedding off a minor girl to a boy, young or elderly man of the grieved party as a compensation for heinous crimes. These crimes include murder, kidnapping, befriending women, adultery and debt payments; exchange marriages at times take place without age consideration. The unholy nexus of religious conservatives and cultural orthodoxies is studied in the paper. This research employed qualitative method in which five persons from three districts of Sindh were interviewed who were married off as a child; secondary sources of data are also taken. It seeks to explore values, norms and social attitudes concerning child marriage practices in Pakistan.
\end{abstract}

\section{INTRODUCTION}

Human exploitation can be dated back to the early beginning of civilization era. Child marriage has been one of the tools to silence the victim's voice. The targeted class enlists the lesser human gender (females), poor peasants, child laborers and other weak people. Many national and international organizations have admitted that it is very difficult to get exact percentage of early marriages in several developing countries as many people do not go for marriage registration. In most of the rural areas of these countries, most of the child births remain unregistered which make this problem more 
severe because it's difficult to determine the age at the time of marriage. According to UNICEF, 64 million young women (aged 20-24) are married before the age of 18 (Sibanda, 2011). 14.2 million girls are forcefully married every year(Greene, 2014). In South Asia, child marriage is one of the common practices and second highest in the world (Naveed \& Butt, 2015). In this region, nearly half of all girls marry before they reach the age of 18. According to UNICEF's 2016 statistics of Pakistan, $3 \%$ girls got married at the age of 15 and $21 \%$ at the age of 18(Brides, 2017). The percentage of child marriages in rural areas of Pakistan is higher (37 percent) than urban areas (21 percent). Child marriage is a cultural and traditional norm in Pakistan and this practice has continued across generations leaving behind devastating effects on the lives of the girls, families and society. It is not only a human rights issue or a missing opportunity for those young girls, these marriages have serious consequences. People do not talk about it because they view it as a family matter. Cultural legacies don't allow the practice to be considered a violation of the human rights.

Child marriages affect victims badly and injure them emotionally and physically. It impedes their overall development, education and employment opportunities and they suffer for their whole lives. It has transcended from a human rights into a developmental issue. Women are considered financial burdens in most of the South Asian countries: marrying them off at a premature age is considered as an economic relief. Most studies conclude that child marriages are mostly practiced by poor and uneducated families.

Pakistan's child marriage restraint act (CMRA) 1929 is the primary law that defines the age restrictions and penalties related to the notion of child marriages. It sets the minimum age limit: 18 for boys and 16 for girls. Child marriage problem has been hurting Pakistan in many ways and is raising serious questions. Girls are more than half of the population of Pakistan(Nasrullah, Zakar, Zakar, \& Krämer, 2014). so how can you improve females' education when they are taken out of schools to be married? How can you control maternal and child mortality when girls are giving births at the age of 12 or 13 ? How can you reduce poverty when child marriage perpetuates poverty? Most of the studies show that child marriages affect girls far more than boys in Pakistan. Lawmakers have made strong laws to curtail child marriages though intentions can't be measured. A proposal for making the age barrier same for both the genders was initiated i-e 18 for all, but the National Assembly, dominated by the conservative landlords, rejected the draft in May, 2017. Harsher penalties were passed, but the age enhancement wasn't compromised. The interesting fact is that the Sindh Assembly had already passed a bill for '18 for all' in April, 2014, but the ground situation isn't satisfactory(Jillani, 2015).

Jirga customs have also maligned family relationships in Pakistan. Village councils don't consider child marriages a violation of human rights. They take pride in early marriages since women aren't considered worthy enough to be given such a luxurious right: these Jirga councils don't have any woman member and they are not allowed to give their consent on any issue. 


\section{BACKGROUND}

Generations have passed on the tradition of child marriages. Globalization has challenged the practice since the advanced countries don't really allow gender inequality. But the subservient societies take the issue as a matter of pride: voice is raised immediately calling it western meddling in the personal affairs of the country. Women emancipation is a concept in the embryonic stage(Hali, 2013). People practice it in the west; people debate it in the developing sub-continent; people loath the concept in the conservative tribal society of Pakistan. One third of the girls in the developing nations are married off before turning to eighteen, which is an alarming statistic. According to UNICEF, Pakistan does not come in the top 20 countries percentage wise, but it is ranked sixth in the number of child marriages i-e 1,875,000 (data from 2008-2014). Pakistan is having troubles in curtailing the percentage of child marriages, but still there are several countries performing even worse. Taking South Asia for reference, Bangladesh heads the list with a staggering 66 percent of child marriages; Afghanistan comes at two with 51 percent followed by India (47) and Nepal (41)(Khanna, Verma, \& Weiss, 2013). Interested candidates visit such countries to take child brides under legal, religious and cultural protections. This makes the dilemma of child marriages a global menace. Economic factors contribute heavily to teen and pre-teen marriages. In number of African and South Asian countries, males are supposed to run families: their life demands all the comforts available. People tend to adopt a similar behavior either by marrying their own daughter or taking their daughter in law. The purpose is to get rid of the girls early and save money in an already dejected society for the future endeavors. Health and education obviously don't make the list(Abro, 2012). But what they don't understand is that there will be more (not less) mouths to feed when a girl gets married since the birth rate always remains higher than the infant mortality rate. This self-delusional economic model doesn't complement an award. Child marriages advocate sexually transmitted diseases especially when an adult male takes a child bride. The reticence of the orthodoxies on the masculine infidelity seems ephemeral: such experienced men tend to transmit fatal diseases to the infallible souls. Sociological terms like gender equality and human reasoning are not welcome in rural Pakistan. When education isn't prioritized, life gives no choices and people tend to chastise a whistleblower. Child marriages become a blessing in disguise for the men who could offer the society nothing but their natural animalistic reproductive abilities. In Nepal, adolescent boys and girls have started tying the knots as an escape from forced marriages and sexual exploitation whereas the country has a legal age barrier of twenty in the books.

The world has reacted to the sufferings of the oppressed. Millennium Development Goals (MDG's) envisaged by the UN and signed in 2000 by 189 member states, were eight goals finalized in 2001 and divided into targets and deadlines to help the extreme poor half of the world. Though reducing poverty and hunger was the primary goal, it also addressed women emancipation and child mortality (McArthur, 2013). But ending child marriage practice has been added to these goals in 2017 that are to be achieved by 2030. India started Apni Beti Apna Dhan (our daughter our wealth) in which parents were to receive 390 dollars once their unmarried daughter turns eighteen. Child marriage has severe physical, emotional, social and health effects on girls, deteriorating their overall development. Marrying at very early age ends girls' childhood, as well as education and economic opportunities. Moreover, it enhances their risk to violence and physical abuse. The opportunity cost of living a normal life and marrying after twenty instead of opting for child marriages would have 
been magnanimous for the fate of a nation. Let's suppose the percentage of child marriages in a country of 220 million people (Pakistan in this case) to be less than one percent. It means almost every girl and boy is going to have a chance to do something other than getting married prematurely. This does not ensure a full stop on child labor and other child exploitative mechanisms, but it does give a refreshing feeling to the society by allowing its children especially girls to breath with a free will. By turning eighteen, maturity and sense building start to teach the child about making choices in life whether it is a financial or a life partner's choice. This does not mean a forceful shift from arranged towards love marriages. Pakistani society is predominantly based on arranged marriages. That is perfectly fine provided the de facto institution of child marriages gets abolished (Paul Bentley, 2011 ). The efficacy of such an imaginative illustration is to respect the customs and traditions of a country i-e arranged marriages with partial or full consent of the brides could be the norm of that society. But that society needs to know its limits vis-à-vis human and child rights. The worrying sign is that despite of all the unfavorable consequences, child marriages continue unabated. This is indeed a matter of great concern and it requires strict laws and serious actions from the competent authorities.

\section{FACTORS CONTRIBUTING TO CHILD MARRIAGES}

There are multiple socioeconomic and religious factors contributing to the high prevalence of child marriages in Pakistan. Following are the major reasons for this ill practice:

Tribal tradition and Jirgas: Pakistan is home to various cultures and people. Tribal agencies in the north-west share common pushtoon traits with the orthodox Afghanistan. Women in these adjoining regions don't have a right to have a right for something. Interior Sindh in the south has a legacy of the ancient concept of slavery: master slave relationship has a special status for women; even the oppressed masculine slaves possess women as their rightful slaves. In Pakistan's rural regions, (Interior Sindh in the paper) the anti-human rituals e.g. Vani, Sawara (girls given as brides in exchange for dispute settlement) and Paitlikkhi (written on stomach: children are engaged before birth or when they are very young) get full protection from the de facto gatherings of the tribal elders, family headmen and landlords. These are termed Jirgas in the orthodox north-west whereas rural Sindh and south Punjab call them Panchayats. These are not only authoritative assemblies but are well respected even by the public office holders. Rural people don't really understand the Anglo-Saxon legal system of Pakistan: some consider it forbidden in religion; others call it never ending and money consuming. Jirgas provide a substitute under the tagline of speedy justice. But their de facto authority has no boundaries.

Jirgas often settle disputes by 'vani' or 'swara'; the nearest daughter or sister of offender is given to opposite family over the order of these unofficial courts. These forced marriages are considered as dispute settlement between the enemies so there is no wedding ceremony. These girls are even more compromised than other child brides since they are the emblems of a murder being pardoned by assassinating their souls. Such incidents are frequent in rural Pakistan but seldom reported(AFP, 2017).

Sometimes rapes are also ordered. In July 2017, breaking all the records of violation of human rights, a panchayat ordered rape of 17 year old girl by the brother of 12 year old rape survivor in 
Multan, South Punjab(Dawn, 2017). Women corpses set ablaze or girls paraded naked are also the fruits of this parallel justice system (Bandial, 2016). The Rutgers World Population Foundation did a house hold survey in the cities of Dera Ghazi Khan, Jacobabad, Jaffarabad, Muzaffargarh, Kashmore and Naseeraabad. Their finding showed that more than $77 \%$ of marriages were settled under customary practices such as swara, vani and sung chatti ordered by these Jirgas or Panchayats (Brohi, 2016). Out of five thousand women, three fourth were the victims of physical and mental abuse (Brohi, 2016).

These brutalities raise severe human right issues. Such atrocities are indicting on the poor: if a feudal or his son commits adultery or kills a person, very few would dare call for a Jirga or expect a verdict if held. Government has given the village councils a legal status which is a dent to the confidence of the human right activists. In 2006 Supreme Court declared the Jirga rulings illegal.

Though Pakistani rural society is considered orthodox in the west, its tribal traditions easily surpass the Islamic conservative interpretations. These tribal elders value their centuries old traditions more than any other thing may it be religion or a human rights affair. This cultural carnage in Pakistan's rural areas has a byproduct that is hard but interesting to study; even the community leaders and the spiritual personalities turn a blind eye to these rituals. Partly, this association could perhaps be the result of a lack of an alternative or a resistance to change. Changing of attitudes means a rejection of the shameful practices of the forefathers, an honor tribal societies cannot dishonor. Their list of faithful atrocities is long, child marriage is only a petty issue in their eyes and orthodox religious scriptures are used to second the tribal traditions to halt any effort against the child marriages.

Religious Exploitation: Most of the people in Pakistan are orthodox Muslims when it comes to religious interpretations of the holy textures. The role of religious figures in Pakistan is very important as 97 percent population is Muslim. There are different interpretations regarding the child marriage, circumstances of marriage and ages of bride and groom. This has made the worsened the situation. Islam is not precise about the age of a girl's marriage which gives leverage to the religious leaders in Pakistan to interpret this issue in different ways. So many people in Pakistani society believe that child marriage is not forbidden in Islam. Indeed, there is a need to take physical and psychological aspects into account.

The Council of Islamic Ideology (CII) Pakistan has done nothing to ensure women rights and to stop ill practices like rape, vani, swara, karokari and acid crimes. It just endorses men's rights of divorce and polygamy(Zaheer, 2014). They don't allow a common Pakistani to challenge or reason a source from the antiquity. The elite gender in Pakistan is obliged to have additional wives without even taking consent from the existing ones. In such a suffocating society, asking for a delay in the girls' marrying age is considered a sin. In Bangladesh, women are experiencing similar situation. South Asian countries contribute heavily to the numbers of child marriages(Khanna et al., 2013) .

Nikah Khawans, the Islamic religious figures responsible for officially tying the wedlock, don't bother inquiring about the groom's age. Discerning 14 and 16 could be tricky at times, but what about an eight years old girl? This practice has polluted the trust people tend to have in the religious figures. The irony doesn't end here. Religious figures also despise the voices raised against forced marriages, rapes and honor killings. This Mullah-Feudal unholy nexus has dented the very human aspect of the 
society. It is imperative for the female Islamic scholars to come up and show defiance when communicating with the general public. Indonesian female clerics have issued a Fatwa against the child marriages by saying that early marriages are harmful and its prevention is mandatory(Yi, 2017). Though there is consensus that the consent of girl in a marriage in mandatory, but this Islamic principle always gets sidelined as no one likes to discuss it. Our clerics find solace in the euphemism of religious scriptures. They want their audience to get used to listening to their directionless sermons for hours. A more literate preacher may give a talk on the issue of consent in marriage, but the discussion would normally be on the side effects of consenting girls before marriage. This sacred cum illogical class only makes a layman doubtful about the rights of women in Islam; he/she would still find these personalities living in the dark ages with the mindset of a cave dweller. A girl at the age of playing with her siblings might easily be handpicked for the tainted blessing of child marriage. Unanswered queries of the religious complexities have only enhanced the cases of pedophiles. Religious cover to this child exploitation is a stigma on Pakistani democracy and the rights of its citizens. Unfortunately, the admissibility of child marriages isn't limited to Pakistan only. There are countries performing even worse e.g. Bangladesh and the sub Saharan African countries. Islamic interpreters of the marriage laws have made the whole Muslim world strangled in the dilemma of children's psychological persecution i-e child marriages.

Poverty and Curse of Dowry: Poverty is one of the major reasons for early marriage in Pakistan. Most of the studies show that child marriages are mostly practiced by financially poor families. Girls are considered economic burden on the family; therefore, if she gets married that is one mouth less to feed. In rural areas of Pakistan, poverty ratio is higher than urban areas and is the most important cause for the practice of child marriage. In 2005-2006 financial years, 27 percent of population in rural areas was living below the poverty line, as compared to 13.1 in urban areas (Naveed \& Butt, 2015).

Dowry is an issue despised by many, but treated as a societal norm. All classes of the Pakistani society demand dowry from the bride's family. But at the same time, young girls get the best discounts especially if they get married to a partner more than double of their age. In these cases, the girls' families often receive cash payments from the bridegroom. The first step towards the eradication of dowry, at least on paper, has been taken by the Khyber Pakhtunkhwa Assembly as members put a ban on this ancient practice(Khattak, 2017).

Lack of Education: In rural areas of Pakistan, most of the population is illiterate. Uneducated parents do not allow their children to acquire education because of their financial constraints, girls in particular. Girls are often kept out of school because no value is associated with their education, compared to boys. Parents generally do not see benefits in investing on girls' education as they will get married and leave the house.

Institute of social and policy sciences published a report called "public financing of education in Pakistan and agenda for budget 2016-17". Pakistan is the second worst country after Nigeria when it comes to population percentage of children out of school: 24 million to be exact(Tahir, 2017). These children are the primary source of child labor, religious terrorism, human rights violations and of course child marriage. 
Maintaining power control through Exchange Marriages: People tend to give away young girls as completion of an exchange marriage. When we are giving our girl to a family, why not make them oblige us by letting our son marry their daughter. Hence the equation gets balanced. Such mindsets force parents to wed off their young girls to complete (balance) the other family's equation. Decisions of exchange marriages are mostly taken by the heads of families and male members. Most of the girls are not consulted in taking decisions of their wedding. In fact, it is considered 'disrespectful' to take opinion of girl regarding her marriage.

Gender Discrimination: Gender discrimination is the root of destructive traditional practices done against females and young girls and such practices are responsible for furthering the dominant position of men and boys over women and girls in a patriarchal society (Khanna et al., 2013). In conservative society of Pakistan, marriage decisions are taken by fathers and most of the times, girls get married earlier than boys due to economic pressures. Due to lack of education, they remain dependent on their husbands for finances. The UN Committee on the rights of the child articulated strong concern for Pakistan as there is massive gender discrimination in the traditional society of Pakistan regarding the roles and responsibilities of men and women in the family, in the work place and in the society which create serious obstacles to women's enjoyment of their human rights" (UN, 2009).

\section{METHODOLOGY AND RESULTS}

We have gone deep into the Tharparkar desert of Sindh to decipher the hidden complexities of child marriages. Government schools were visited, teachers interviewed and a comprehensive understanding of the everyday's life was unlocked. Choosing interior Sindh meant targeting the highest percentage rate of child marriages. According to the available statistics, Sindh has the highest percentage of early marriages.

Research Subjects: Five persons from three districts i-e Tharparkar, Khairpur and Kambar Shahdadkot were taken as samples. Two women and three men (all married as a child) were included in the sample. We had developed a questionnaire of 10 pertinent socio-economic queries. Participants' particulars were taken before answering the questions one by one. Amira Jogi and Sohni Jogi aged 12 and 15 respectively at the time of their marriage. They had accepted what their elders decided for them. In Jogi tribe, the ruling elders are known as Sardars; their authority and decisions cannot be challenged even if they decree a vani. Third respondent was Danish Ali Jalbani of Khairpur who had married at 17 to a 16 years old cousin. Abid Hussian Mastoi from Shahdatkot married at 16 again to a cousin. Our youngest participant was Abhijeet of only 11 . He got married at 10 . The first question was "Were you consulted before marriage"? All five responded with a resounding 'No'. One respondent (Abhijeet from Mithi, Tharparkar) was shocked to hear about the concept of consultation. Second query was "How did you feel when you were married to a stranger"? These are inter-family/ intra-tribe marriages; cousin marriages in interior Sindh are examples of Paitlikkhi tradition.

Pre-Marriage Understanding: All five of them knew their partners before marriage, so there wasn't much anticipation involved. "Do you know what a child marriage is? How do you comprehend the 
concept?" Abid and Danish knew about these human rights violations, but they were victims of Paitlikkhi and cousin marriages. The other three were neither educated nor had they gotten a decent idea about the repercussions of child marriages. "Why didn't you attend a school? Do you blame your parents? What should be said about the society's role?" Two of them were educated (Danish and Abid) having decent jobs: they didn't like their childhood marriages; their married lives started too early; they were dissatisfied by this societal injustice to their future planning. They did blame their parents for this suffocation of life. The other three respondents blamed society and their tribal elders for keeping them under the darkness of illiteracy. Next questions were "Will you do the same to your children especially girls?" and "Do you engage your children in the childhood?" Both the female respondents didn't really have any urge to change this ongoing practice as they were deeply aligned to their rituals. All the three males disagreed with the female version. Though one respondent, Abhijeet was very young to give a final verdict on his children's future, the other two were adamant to stand against this traditional menace. We asked them "How do you see the tradition of Jirgas?" We have received a response that endorses the power and respect for the tribal elders in their communities. Four of them (Amira, Sohni, Abhijeet and Danish) believed in the overall effectiveness of Jirgas and speedy justice: three (Amira, Sohni and Abhijeet) considered these Sardars (tribal elders) sovereign and worthy of making final decisions while the fourth one (Danish) didn't consider the Anglo Saxon police system of Pakistan fit enough to deal with the rural misadventures. The fifth respondent (Abid) despised this culture of Jirgas.

The Confusing Query: Our eighth question was "Do you prefer customs or religion? Do you understand the difference?" This question's response endorsed the complexities of religion-custom dichotomy prevailing in Pakistan. People tend to fit religion in their quest for the continuation of tribal rituals and cultural legacies. Since interior Sindh also hosts most of the Hindu population of Pakistan, the region has a mixed religious set up with people intermingling in their daily affairs of life. These interactions make the province of Sindh in general and interior Sindh in particular, less uncompromising and more closely connected. But illiteracy is the order of the day making the cultural tendencies taking over the religious bindings. Their responses confirmed the preferences of cultural traditions (especially Jirgas) over religious affairs as all five of them agreed to a supremacy of cultural traditions over religion. Our ninth question was "Does poverty has to do anything with child marriage?" Interestingly, three of them disagreed. Two respondents (Danish and Abid) considered tribal traditions and societal norms as the contributory factors while the third respondent (Abhijeet) respected child marriage as a continuation of tribal customs. Two of the respondents (Danish and Abid) had the understanding of child marriages according to the definition of CMRA. The remaining two respondents (Amira and Sohni) blamed poverty for their early marriages and the miserable lives they were living.

Game Changing Answer: The last question was "Have you ever been beaten by your husband and vice-versa? Is it normal?" This was the most eye opening moment in the research. Everyone had complained either about poverty, early marriages or jirga power, but no one answered this question in a yes. The respondents even laughed when asked about beating their life partners. So the supposition of a correlation between poverty, illiteracy and wife beating ended up in a null 
hypothesis. These people had all the problems related to society and government, but they have learnt to coexist in a less violent manner.

Corroborating Research: In the quest for ground realities, we had also visited government schools, women medical care centers and hospitals in the rural Sindh. We met school teachers, laboratory personnel and child dispensary workers. A detailed communication in Urdu and Sindhi languages took place; some of them shared our concerns and they gave every little detail they had about the ground situation in rural Sindh. By these comprehensive meetings, we have unearthed that poverty sucks the cost of opportunities; child marriages don't allow the age of awareness to interfere in the centuries old traditions; illiteracy shuts every possible chance of a thought revival among the general masses; those in power (Panchayats' leaders, Sardars and Tribal elders) know about the status of the poor and their own dichotomies; the affected bourgeoisie often endorse the prevailing customs since people in Pakistan take pride in associating with their castes and tribes. Jirga organizers play deep into the hearts of the poor: they choose the fraudulent youth within the ultra poor tribes, give them power to implement orders (even if their own families get compromised) and then use carrot and stick model to frighten already subdued Homo sapiens.

Key Point: We found out that the respondent's understanding to our questions depended upon their education standards. The educated respondents (2) were keen to respond and add their advices as well. Whereas the illiterate respondents (3) were initially bamboozled by these queries since they didn't expect someone to ask about the parental problems they were facing in such young ages. Education also discerned the thought process. Illiterate respondents would happily continue doing the same with their children whereas the educated ones have already taken a psychological stand against the rituals like Paitlikkhi for their children.

We had also interviewed the officer Sadia Cheema of Awaaz NGO Pakistan and Senator Sehar Kamran from Pakistan people's party about the dilemma of child marriages. Awaaz organization deals in various socio economic issues like gender inequality and child marriages along with arranging seminars on the awareness for the rights of rural population, we found Sadia's experience pertinent to our research. She called the choosing of partners as the choosing of future. This future would end up nurturing or devastating a generation. She said that apart from health issues, these marriages have severe consequences that effect child, family and society at large. As a social worker and mother of three, she herself is an example for the rural women. She said that you can fight for your rights but you need to feel the need for rights first. This urge shouldn't be missing in the 21st century. Though efforts are being made by several institutions and donor agencies to bring awareness among the common masses, the problem is so deeply interwoven that it will take decades to give results provided further efforts are made in this matter.

Senator Sehar kamran took the initiative and presented the bill in the senate for girl's age restriction from 16 to 18 for marriage in 2017 which was unfortunately rejected as they called it unislamic. She said that I got both positive support and negative reactions for my step. She said that no society can grow without the active contribution and full participation of its women, and that we believe that young generations are the future of this country and we have fought and sacrificed a lot for the survival of this country. But when push comes to shove, we continue to be disinclined to save them, 
and afford them the opportunities they need to blossom. According to her, it is most important to save our girls from becoming child brides, in order for them to accomplish their true potentials as the cruxes of their families, and productive citizens of this great country. The reasons and justifications we produce are also multifold; poverty, misuse of the 'culture' and 'tradition' narratives, lack of education, and a patriarchal 'system' deeply embedded with power-related/political motivations.

\section{CONCLUSION}

Child marriages are a direct violation of human rights. Old customs act as obstacles in taking actions against this practice. Though developed countries are aware of this dilemma and have raised voice against it, yet the under developed and the developing countries are experiencing a high percentage of child marriages. We have found that education is the most important independent variable in deciding the fate of a mother or even a community. It is directly proportional to the level of awareness: unawareness could bring death; it normally brings poor health to the mother. People also use religion as an escape goat to continue practicing child marriages. In Pakistan, ancient customs like Paitlikkhi and Vani need child marriages (forced marriages) to flourish. The ideological council of Islam in Pakistan is also in favor of early marriages. They discard any attempt by the civil society or any talks with the government on early marriages and family planning. The feudal lords are also in an unholy alliance with the clergy men and ancient customs. They support child marriages because it serves their interests. According to them, education brings independence; independence is not for women; early marriages allow the structure of society to remain still. Pakistan has a low rate of divorce: this is partly due to these stringent thoughts and practices. Patriarchal society i-e a male dominated social order, has made the reduction in child marriages a serious challenge for Pakistan. Though we are not advocating a radical feminist approach to turn the tables, but Pakistan has suffered from the practice of child marriages due to its denial to listen to voices other than that of religious scholars, wealthy politicians and jirga leaders. We have also realized that people have started questioning courtesy of awareness by globalization, but still it would take time and a sincere governmental effort is needed to eradicate illiteracy first followed by other socio economic challenges.

\section{RECOMMENDATIONS}

The "Theory of Change" by Girls Not Brides is the best initiative to end the shameful practice of child marriages. The theory is made up of a four pronged strategy: empower girls of the concerned demographics; persuade families and mobilize communities; cooperate with the society by providing pertinent services and make the laws of the land talk and be implemented. This seems to be a perfect solution to address the cause, but it is easier said than done. Talk to the 'boys and men' is the organization's initiative: make them realize of the loss of potential of these child brides to the society. Their only contribution is to give more births which are a serious insult to a gender that represents half of the world's population. Talk to the 'religious scholars' to allow these vulnerable creatures to exist if not co-exist. Let them attain a reasonable age, say 19 or 20, before getting married. Ask these religious powers to use the holy verses of educating a mother, to let them think beyond raising numerous children in addition to staying calm when beaten by the holy husband. Communicating at the societal level is mandatory. The government of Pakistan should formulate a policy that enables a 
smooth transition of justice system from the jaws of Panchayats to the rule of law. The country needs to devise medium and long term strategies to abolish the de facto institution of Jirgas. Nothing is impossible. The only thing this miracle needs is the government of Pakistan to understand the necessity of abolishing the practice of child marriages.

Increasing of age of marriage is a documentary change. Societal management means awareness campaigns, school recruitment measures, spending on health and education of the poor. Islamabad's percentage of education expenditure to total GDP is among the lowest in the world especially in the primary education. Government must consider the spending on education as an expenditure on development. The fruits of such an investment are harvested a bit late but they are long lasting (just like the life span of a generation). Pakistan's dilemma of child marriages is as serious as terrorism: the latter kills people whereas the former kills generations. So, curtailing child marriages percentage is a difficult yet possible task.

\section{REFERENCES}

Abro, H. (2012). Women's Health Issues Retrieved 20 August, 2017, from https://www.pakistantoday.com.pk/2012/04/05/women\%E2\%80\%99s-health-issues/

AFP. (2017). Women as 'collateral' in jirga justice Retrieved 15 August, 2017, from https://www.dawn.com/news/1350084

Bandial, S. (2016). Jirga justice Retrieved 25 August, 2017, from https://tribune.com.pk/story/1100062/jirga-justice/

Brides. (2017). Girls not Brides Retrieved 21 August, 2017, from http://www.girlsnotbrides.org/childmarriage/pakistan/

Brohi, N. (2016). Women, Violence and Jirgas, Review study for the National Commission on Status of Women.

Dawn. (2017). Panchayat-ordered rape Retrieved 25 August, 2017, from https://www.dawn.com/news/1348129

Greene, M. (2014). Ending Child Marriage in a Generation. What Research is Needed.

Hali, S. M. (2013). women Empowerment Retrieved 20/09, 2017, from http://nation.com.pk/columns/08-May-2013/women-empowerment

Jillani, A. (2015). Child Marriage Retrieved 25-09-2017, 2017, from http://www.sparcpk.org/2015/Other-Publications/CM.pdf

Khanna, T., Verma, R., \& Weiss, E. (2013). Child marriage in South Asia: Realities responses and the way forward.

Khattak, S. (2017). K-P slaps ban on dowry Retrieved 20 August, 2017, from https://tribune.com.pk/story/1344507/k-p-slaps-ban-dowry/

McArthur, J. W. (2013). Own the goals: What the Millennium Development Goals have accomplished. Foreign Affairs, 92(2), 152-162.

Nasrullah, M., Zakar, R., Zakar, M. Z., \& Krämer, A. (2014). Girl-child marriage and its association with morbidity and mortality of children under 5 years of age in a nationally-representative sample of Pakistan. The Journal of pediatrics, 164(3), 639-646.

Naveed, S., \& Butt, K. M. (2015). Causes and consequences of child marriages in South Asia: Pakistan's perspective. South Asian Studies, 30(2), 161. 
Paul Bentley. (2011). Why an arranged marriage 'is more likely to develop into lasting love, Retrieved 5 september, 2017, from http://www.dailymail.co.uk/news/article-1363176/Why-arrangedmarriage-likely-develop-lasting-love.html

Sibanda, M. (2011). Married too Soon: Child Marriages in Zimbabwe. The Research and.

Tahir, D. P. (2017). Education spending in Pakistan, from https://tribune.com.pk/story/1490941/education-spending-pakistan/

UN. (2009). COMMITTEE ON THE RIGHTS OF THE CHILD

Yi, B. L. (2017). Female Muslim Clerics In Indonesia Issue Fatwa Against Child Marriage Retrieved 28 August, 2017, from http://www.huffingtonpost.com/entry/female-muslim-clerics-inindonesia-issue-fatwa-against-child-marriage us 59037b6ce4b02655f83d1fb7

Zaheer, K. (2014). Child marriage Retrieved 25 August, 2017, from https://www.dawn.com/news/1096020

\section{Corresponding Author}

Sobia Jamil, Faculty of Law and International Relations, University of Sultan Zainal Abidin, Gong Badak Campus, 21300 Kuala Nerus, Terengganu, Malaysia, Email: sobiajamil09@gmail.com 